\title{
sciendo
}

\author{
BEATA PAWŁOWSKAㄹ , EMILIA POTEMBSKA², JOLANTA SZYMAŃSKA ${ }^{3}$
}

\section{Demographic and family-related predictors of online gaming addiction in adolescents}

\begin{abstract}
Introduction. Dependence on the Internet and online games is a growing problem worldwide.

Aim. The aim of this study was to determine the differences between girls and boys as well as between adolescents living in urban vs. rural areas in regard to prevalence of playing online games, the amount of time devoted to playing games, the severity of symptoms of online gaming addiction, and preferences for game genres. Also, significant predictors of online game addiction in the studied group of young people were identified.

Material and methods. The study involved 827 adolescents aged 14 to 19 years. When it comes to 488 (60.02\%) of them, they lived in the countryside and 325 (39.98\%) in a city. The following instruments were used: a sociodemographic questionnaire, the Online Gaming Addiction Questionnaire and the Disturbed Family Relations Questionnaire, all developed by Pawłowska and Potembska.

Results. Statistically significant differences were found between girls and boys and between adolescent urban and rural dwellers in prevalence of playing online games, severity of online gaming addiction symptoms, preferences for specific game genres, and the amount of time spent playing online games.

Conclusions. 1. Significantly more boys than girls played online games. Boys devoted more time to playing and had more severe symptoms of addiction to online games. 2. Adolescent city dwellers spent significantly more time playing online games, mainly to relieve boredom and experience new sensations, than young people living in the countryside. 3. Major predictors of online gaming addiction included male gender, urban residence, domestic violence, mother's child-raising rules being challenged by the father, and the child's sense of responsibility for his/her parents.
\end{abstract}

Keywords: Internet Gaming Disorder, adolescents, family predictors, demographic predictors.

DOI: $10.2478 /$ pjph-2018-0002

\section{INTRODUCTION}

For several years now, physicians and psychologists have shown increasing interest in the problems of Internet addiction and online gaming addiction [1]. In 2013, the American Psychiatric Association (APA) described the criteria for Internet Gaming Disorder (IGD) in DSM-5 [2]. Müller et al. [3], who conducted a study of Internet Addictive Behaviours among European Adolescents (EU NET ADB) on a group of 12,938 individuals aged from 14 to 17 years, found that the criteria for IGD were met by $1.6 \%$ of their respondents and that $5.1 \%$ of the European respondents met the criteria for the risk of IGD. Lopez-Fernandez et al. [4] estimated that the criteria for IGD were met by $7.7 \%$ of adolescents in Spain and by $14.6 \%$ in Great Britain. Porter et al. [5] showed that $8 \%$ of the young people they surveyed excessively played computer games. Grüsser et al. [6] reported that $12 \%$ of online gamers met the criteria for Internet addiction, and Thomas and Martin [7], Kuss and Griffiths [8] and Jeong and Kim [9] established that from $2.2 \%$ to $5 \%$ of adolescents in their samples were addicted to online video games.

It is estimated that the problem of excessive playing of video games may concern from $1.7 \%$ to $11.9 \%$ of young people [6,10-14], depending on the country and the diagnostic criteria used. Worryingly, this number is on the rise $[6,15]$. Among the problems related to pathological video games use, researchers point to differences in game preferences between boys and girls $[16,17]$ and differences in playing time between boys and girls $[13,18,19]$ and between older and younger game users [7].

Among the psychological effects of excessive video game playing, specialists mention disturbed peer-to-peer relationships [20-22], concentration and attention deficits [23,24], school problems and truancy $[9,12,25]$, suicidal ideation [12,26,27], obsessive behaviour [28] and depressive symptoms $[18,26,28]$. Given these facts, research aimed at identifying the risk factors of online gaming addiction seems to be topical and consequential.

\footnotetext{
${ }^{1}$ II Department of Psychiatry and Psychiatry Rehabilitation, Medical University of Lublin, Poland

${ }^{2}$ Specialist Individual Medical Practice, Kolonia Piotrków, Poland

${ }^{3}$ Department of Integrated Paediatric Dentistry, Medical University of Lublin, Poland
} 


\section{AIM}

The aim of this study was to determine the differences between girls and boys as well as adolescents living in urban vs. rural areas in regard to prevalence of playing online games, the amount of time devoted to playing games, the severity of symptoms of online gaming addiction, and preferences for game genres. We also wanted to identify significant predictors of online game addiction in the studied group of young people.

\section{MATERIAL AND METHODS}

The participants were 827 adolescents (525 girls and 288 boys) aged 14-19 years. The mean age of the participants was 17.12 years, $\mathrm{SD}=1.19$ years. All participants were secondary-school students from Lublin Province. As many as 488 $(60.02 \%)$ respondents lived in the country and 325 (39.98\%) in a city.

The following instruments were used in this study:

1. a socio-demographic questionnaire for collecting data on the participants' age, gender, education and place of residence.

2. The Online Gaming Addiction Questionnaire (Kwestionariusz do Badania Uzależnienia od Gier Internetowych, KBUGI) designed by Potembska and Pawłowska for assessing the symptoms of dependence on online games. KBUGI consists of four scales: Loss, Entertainment and Search for New Stimuli, Compensation and Escape, and Violence and Domination [29].

3. The Disturbed Family Relations Questionnaire (Kwestionariusz do Badania Zaburzonych Relacji w Rodzinie, KBZRR II) by Pawłowska, which contains 58 items on seven scales: Lack of Acceptance and Understanding, Symbiosis, Alliance with the Mother, Alliance with the Father, Regression, Role Reversal and Violence [30], is used to determine abnormal parent-child relationships.

Two independent groups were compared using the $\chi^{2}$ test for nominal variables and student's t-test for interval variables. Based on linear forward stepwise regression, demographic and social (family-related) variables which were important predictors of online gaming addiction (measured by the global KBUGI scale) were identified. A p value of 0.05 was deemed statistically significant. All data analyses were performed using STATISTICA PL, version 10.

\section{RESULTS}

In the first stage of the study, the prevalence of online gaming was assessed in the group of adolescent respondents, taking into account their gender and place of residence. As many as $631(83.69 \%)$ of the respondents played online games. This number included significantly more boys than girls $(\mathrm{N}=267$; $95.02 \%$ vs. $\left.N=364 ; 76.96 \% ; \chi^{2}=42.13 ; p=0.001\right)$. Significantly more of the online game players lived in urban areas than in rural areas $\left(\mathrm{N}=258 ; 87.16 \%\right.$ vs. $\mathrm{N}=366 ; 81.51 \%, \chi^{2}=4.18$, $\mathrm{p}=0.04$ ).

The results of student's t-test showed that boys spent significantly more time (hours per week) playing online games than girls $(\mathrm{M}=2.66 ; \mathrm{SD}=0.94$ vs. $\mathrm{M}=1.87 ; \mathrm{SD}=0.81 ; \mathrm{t}=12.41$; $\mathrm{p}=0.001$ ). Young city dwellers devoted significantly more time to playing than their peers from the countryside $(\mathrm{M}=2.25$;
$\mathrm{SD}=0.94$ vs. $\mathrm{M}=2.09 ; \mathrm{SD}=0.94 ; \mathrm{t}=2.28 ; \mathrm{p}=0.02$ ). Boys living in a city and in the countryside did not differ significantly with regard to the amount of time they spent playing online games $(\mathrm{M}=2.74 ; \mathrm{SD}=0.96$ vs. $\mathrm{M}=2.63 ; \mathrm{SD}=0.93 ; \mathrm{t}=0.92 ; \mathrm{p}=\mathrm{ns})$. By contrast, girls living in a city devoted significantly more time to playing online games than those living in the country $(\mathrm{M}=2.01 ; \mathrm{SD}=0.83$ vs. $\mathrm{M}=1.77 ; \mathrm{SD}=0.79 ; \mathrm{t}=3.36 ; \mathrm{p}=0.001)$.

The results of the $\chi^{2}$ test, which was used to compare the number of girls and boys playing specific genres of games, indicated that boys were significantly more likely than girls to play sports games $\left(56.66 \%\right.$ vs. $\left.22.50 ; \chi^{2}=97.14 ; p=0.001\right)$, racing games $\left(54.95 \%\right.$ vs. $\left.33.46 ; \chi^{2}=35.96 ; \mathrm{p}=0.001\right)$, shooter games $\left(54.61 \%\right.$ vs. $\left.16.82 ; \chi^{2}=127.48 ; \mathrm{p}=0.001\right), \operatorname{FPP}(29.01 \%$ vs. $\left.6.99 ; \chi^{2}=72.31 ; \mathrm{p}=0.001\right)$, economic simulation games ( $26.62 \%$ vs. $\left.8.62 ; \chi^{2}=48.46 ; p=0.001\right)$, military games (war games) $\left(35.85 \%\right.$ vs. $\left.6.99 ; \chi^{2}=112.04 ; \mathrm{p}=0.001\right)$, RPG $(32.76 \%$ vs. $\left.7.18 ; \chi^{2}=90.44 ; \mathrm{p}=0.001\right)$, fighting games and beat 'em ups (brawlers) $\left(23.55 \%\right.$ vs. $\left.7.79 ; \chi^{2}=40.17 ; p=0.02\right)$, combat games $\left(17.41 \%\right.$ vs. $\left.3.59 ; \chi^{2}=46.19 ; \mathrm{p}=0.001\right)$, and MMORPG $\left(27.65 \%\right.$ vs. $\left.5.10 ; \chi^{2}=83.95 ; \mathrm{p}=0.001\right)$. Significantly more girls than boys played logic games $\left(46.69 \%\right.$ vs. $36.86 \% ; \chi^{2}=7.43$; $\mathrm{p}=0.006$ ).

The results of the $\chi^{2}$ test showed that young city dwellers were significantly more likely than their peers from the countryside to play action games $\left(48.77 \%\right.$ vs. $\left.40.25 ; \chi^{2}=5.74 ; p=0.02\right)$, adventure games $\left(41.05 \%\right.$ vs. $\left.34.29 \% ; \chi^{2}=3.81 ; \mathrm{p}=0.05\right)$, strategic-economic games $\left(17.90 \%\right.$ vs. $\left.12.96 \% ; \chi^{2}=3.73 ; \mathrm{p}=0.05\right)$ and beat 'em ups $\left(22.22 \%\right.$ vs. $\left.14.58 \% ; \chi^{2}=7.83 ; \mathrm{p}=0.001\right)$.

Significantly more boys living in urban areas than those from rural areas played economic simulation games $(33.02 \%$ vs. $\left.22.65 \% ; \chi^{2}=3.69 ; p=0.05\right)$, and significantly fewer of the former played racing games $\left(42.45 \%\right.$ vs. $62.98 \% ; \chi^{2}=11.40$; $\mathrm{p}=0.001$ ).

Compared to their peers from the countryside, girls living in a city were significantly more likely to play sports games $\left(26.61 \%\right.$ vs. $\left.18.69 \% ; \chi^{2}=4.65 ; p=0.03\right)$, action games $(44.95 \%$ vs. $\left.33.11 \% \mathrm{X}^{2}=7.56 ; \mathrm{p}=0.01\right)$; shooter games $(22.94 \%$ vs. $\left.11.80 \% ; \chi^{2}=11.47 ; \mathrm{p}=0.001\right)$, adventure games $(41.74 \%$ vs. $\left.31.80 \% ; \chi^{2}=5.46 ; \mathrm{p}=0.02\right)$, strategic military games $(9.63 \% \mathrm{vs}$. $\left.5.25 \% ; \chi^{2}=3.72 ; \mathrm{p}=0.05\right)$, RPG $\left(10.55 \%\right.$ vs. $4.26 \% ; \chi^{2}=7.82$; $\mathrm{p}=0.005)$, MMORPG $\left(7.80 \%\right.$ vs. $\left.3.28 \% ; \chi^{2}=5.30 ; \mathrm{p}=0.02\right)$, fighting games and beat' 'em ups $\left(26.61 \%\right.$ vs. $12.13 \% ; \chi^{2}=17.92$; $\mathrm{p}=0.001)$, and combat simulations $\left(5.50 \%\right.$ vs. $2.30 \% ; \chi^{2}=3.74$; $\mathrm{p}=0.05)$.

Table 1 shows the results of student's t-test, which was used to compare the severity of video gaming addiction symptoms measured by KBUGI scales in girls and boys.

TABLE 1. Comparison of girls' and boys' scores on KBUGI scales.

\begin{tabular}{lcccccc}
\hline \multirow{2}{*}{ KBUGI scales } & \multicolumn{2}{c}{ Boys } & \multicolumn{2}{c}{ Girls } & \multirow{2}{*}{ t } & p \\
\cline { 2 - 5 } & $\mathbf{M}$ & SD & M & SD & & \\
\hline Loss & 0.37 & 0.61 & 0.13 & 0.32 & 5.93 & 0.001 \\
\hline $\begin{array}{l}\text { Entertainment and Search } \\
\text { for New Stimuli }\end{array}$ & 1.07 & 0.80 & 0.60 & 0.65 & 7.84 & 0.001 \\
\hline Compensation and Escape & 0.40 & 0.60 & 0.19 & 0.38 & 4.98 & 0.001 \\
\hline Violence and Domination & 0.82 & 0.93 & 0.36 & 0.65 & 6.97 & 0.001 \\
\hline KBUGI global score & 77.09 & 76.65 & 35.70 & 48.77 & 7.88 & 0.001 \\
\hline
\end{tabular}


Boys had significantly more severe symptoms of video game addiction measured by KBUGI compared to girls. Boys were significantly more likely than girls to reduce the amount of time they were supposed to spend learning, working, pursuing hobbies, and maintaining family relationships in favour of playing online games. They were also significantly more likely to make unsuccessful attempts at cutting down on gaming time and report a constant need to increase the frequency and amount of gaming. Boys were significantly more likely to have learning difficulties at school due to playing online games and also to lie to their families about the amount of time they had spent playing. Compared to their female counterparts, male participants, were more likely to feel anxious when they did not have access to online games and more often reported that they played games to relieve boredom, boost their mood, compete with others and experience new sensations. Boys were much more likely than girls to treat online games as a way of escaping from conflicts and loneliness. Gaming made them feel more important, more competent, and stronger than they really were. Boys were significantly more likely to choose games in which they could break traffic rules and show aggressive behaviour marked by violence and power seeking.

Table 2 shows the scores obtained on KBUGI scales by urban and rural teens who play online games.

TABLE 2. Comparison of KBUGI scores obtained by urban and rural residents.

\begin{tabular}{|c|c|c|c|c|c|c|}
\hline \multicolumn{7}{|c|}{ Entire group } \\
\hline \multirow{2}{*}{ KBUGI scales } & \multicolumn{2}{|c|}{ Rural } & \multicolumn{2}{|c|}{ Urban } & \multirow{2}{*}{$t$} & \multirow{2}{*}{$\mathbf{p}$} \\
\hline & $\mathbf{M}$ & SD & $\mathbf{M}$ & SD & & \\
\hline Loss & 0.22 & 0.47 & 0.26 & 0.50 & -0.92 & 0.360 \\
\hline $\begin{array}{l}\text { Entertainment and Search } \\
\text { for New Stimuli }\end{array}$ & 0.75 & 0.75 & 0.89 & 0.76 & -2.14 & 0.033 \\
\hline Compensation and Escape & 0.25 & 0.46 & 0.31 & 0.53 & -1.35 & 0.176 \\
\hline Violence and Domination & 0.53 & 0.78 & 0.62 & 0.87 & -1.33 & 0.183 \\
\hline KBUGI global score & 50.10 & 65.11 & 58.78 & 65.83 & -1.56 & 0.120 \\
\hline \multicolumn{7}{|c|}{ Boys } \\
\hline \multirow{2}{*}{ KBUGI } & \multicolumn{2}{|c|}{ Rural } & \multicolumn{2}{|c|}{ Urban } & \multirow{2}{*}{$t$} & \multirow[b]{2}{*}{$\mathbf{p}$} \\
\hline & M & SD & $\mathbf{M}$ & SD & & \\
\hline Loss & 0.34 & 0.58 & 0.40 & 0.65 & -0.78 & 0.437 \\
\hline $\begin{array}{l}\text { Entertainment and Search } \\
\text { for New Stimuli }\end{array}$ & 1.02 & 0.79 & 1.17 & 0.82 & -1.41 & 0.160 \\
\hline Compensation and Escape & 0.38 & 0.58 & 0.41 & 0.61 & -0.42 & 0.677 \\
\hline Violence and Domination & 0.80 & 0.90 & 0.86 & 1.00 & -0.48 & 0.634 \\
\hline KBUGI global score & 73.07 & 74.90 & 83.34 & 78.64 & -1.02 & 0.310 \\
\hline \multicolumn{7}{|c|}{ Girls } \\
\hline \multirow{2}{*}{ KBUGI } & \multicolumn{2}{|c|}{ Rural } & \multicolumn{2}{|c|}{ Urban } & \multirow{2}{*}{ t } & \multirow{2}{*}{$\mathbf{p}$} \\
\hline & M & SD & M & SD & & \\
\hline Loss & 0.11 & 0.30 & 0.16 & 0.35 & -1.55 & 0.122 \\
\hline $\begin{array}{l}\text { Entertainment and Search } \\
\text { for New Stimuli }\end{array}$ & 0.51 & 0.62 & 0.72 & 0.66 & -2.91 & 0.004 \\
\hline Compensation and Escape & 0.14 & 0.28 & 0.25 & 0.47 & -2.53 & 0.012 \\
\hline Violence and Domination & 0.27 & 0.55 & 0.47 & 0.75 & -2.72 & 0.007 \\
\hline KBUGI global score & 29.30 & 46.18 & 43.64 & 51.20 & -2.64 & 0.009 \\
\hline
\end{tabular}

\section{DISSCUSSION}

The results of the statistical analyses showed that $83.69 \%$ of the young people aged from 14 to 19 who took part in the experiments played online games. Statistically significant differences were found between girls and boys and between adolescent urban and rural dwellers in prevalence of playing online games, severity of online gaming addiction symptoms measured by KBUGI, and the amount of time spent playing

online games. In a study of a sample of Polish adolescents,

In the entire study group, city dwellers, compared to their peers living in the countryside, were more likely to play online games to relieve boredom, boost their mood, and experience and new sensations. Girls living in a city had significantly more severe symptoms of addiction to online games than signifiving in the countryside. Girls from urban areas were to experience new sensations, feel more important, better and stronger than they really were, escape from problems, conflicts and loneliness, and express aggression. Male urban and rural residents did not differ significantly in their KBUGI scores.

As a final step of this study, results of linear forward stepwise regression were used to identify demographic and social (family-related) variables which were important predictors of video gaming addiction, as measured by the global KBUGI . The independent variables entered into a linear regression equation were age and gender of the respondents, their Relations Questionnaire.

Table 3 shows the results of linear forward stepwise regression for the dependent variable 'Global KBUGI Score'.

Score'.

\begin{tabular}{lcccccccc}
\hline \hline $\begin{array}{l}\text { Independent } \\
\text { variables }\end{array}$ & $\mathbf{R}$ & $\mathbf{R}^{2}$ & $\mathbf{F}$ & $\mathbf{p}$ & Beta & $\mathbf{B}$ & $\mathbf{t}$ & $\mathbf{p}$ \\
\hline Violence & 0.34 & 0.11 & 60.11 & 0.001 & 0.20 & 16.68 & 4.32 & 0.001 \\
\hline Gender & 0.45 & 0.20 & 49.51 & 0.001 & -0.31 & -42.98 & -7.76 & 0.001 \\
\hline $\begin{array}{l}\text { Alliance with } \\
\text { the Father }\end{array}$ & 0.48 & 0.23 & 22.12 & 0.001 & 0.17 & 15.77 & 3.46 & 0.001 \\
\hline $\begin{array}{l}\text { Role } \\
\text { Reversal }\end{array}$ & 0.49 & 0.24 & 5.10 & 0.024 & 0.11 & 8.92 & 2.33 & 0.020 \\
\hline $\begin{array}{l}\text { Place of } \\
\text { Residence }\end{array}$ & 0.50 & 0.25 & 4.35 & 0.038 & 0.08 & 11.57 & 2.09 & 0.038 \\
\hline
\end{tabular}

The following factors turned out to be significant predictors of video game addiction: the demographic factors - male gender and urban residence, and the family-related factors taking the father's side in situations of conflict between parents, the father mitigating the mother's parenting principles order to present himself to the child as the "better parent", and the child's belief that he/she is responsible for his/her parian. Taken together, these variables explained $25 \%$ of the studied. Experiences of violence explained $11 \%$ of variance in the dependent variable, male gender $-9 \%$, alliance with the father $-3 \%$, sense of responsibility for parents $-1 \%$ and urban residence $-1 \%$. - experiences of psychological and physical parental abuse, 
Bobrowski [31] found that $74 \%$ of third-grade junior high school (gymnasium) students from Warsaw schools used the Internet daily and $64 \%$ played computer games daily. Boron and Zyss [32] established that the problem of computer games concerned $56 \%$ of the population sample they studied. Thomas and Martin [7] reported that among young Australians, 73.6\% of primary school students, $56.7 \%$ of secondary school students and $26.2 \%$ of university students played online games. In the United States, as many as $88 \%$ of Americans between the ages of 8 and 18 occasionally play computer games [11]. A study conducted in Norway [33] on a group of 3,337 young people aged between 12 and 18 showed that $63.3 \%$ of them regularly played computer games. Porter et al. [5], based on an online study of English-speaking participants of Internet fora for over-14-year-old players from around the world, determined that the problem of pathological online gaming concerned online game aficionados, who represented $75.6 \%$ of the surveyed group.

The results of the present study show that there are more boys than girls playing online games. Boys spend significantly more time each day playing online games and have significantly more severe symptoms of Internet gaming addiction than girls. Most studies confirm that boys and men spend more time playing computer games and that they are more likely than women to meet gaming addiction criteria $[13,19]$. Dependence on playing video games is more prevalent among boys (78\%) than girls (40\%) [32,34]. According to Poprawa [34], in the Polish population, there are more men than women who play online games. German researchers [12] have shown, in a nation-wide study, that $4.7 \%$ of German boys are at risk of video gaming addiction and 3\% meet addiction criteria. The problem of Internet gaming addiction is ten times less severe in the population of girls compared with the population of boys.

The results obtained in the present study show that significantly more young online game users live in cities than in the countryside. City dwellers spend significantly more time playing online games; they are more likely to play to relieve boredom, boost their mood, and experience new sensations than people living in the countryside. Women living in cities have significantly more severe symptoms of addiction to online games than their peers from rural areas. A higher prevalence of online gaming in city dwellers compared to inhabitants of the countryside was reported by Pawłowska et al. [35] in a previous study conducted on Polish teenagers of a similar age group. In those studies, the authors showed that girls living in cities were more likely to play violent online games than their peers from the countryside.

The analysis of the types of games played by men and women revealed that significantly more men played sports, racing, shooter, FPP, economic simulation, military, fighting, and combat games as well as RPGs and MMORPGs, while women preferred logic games. Significantly more young city dwellers than their peers living in the country played action, adventure, strategic-economic and fighting games. Boys living in the country preferred playing racing games, while their urban counterparts preferred economic simulation games. Significantly more girls living in a city than those from the countryside played sports games, action games, shooter, adventure, strategic military games, RPG, MMORPG, beat 'em ups and combat simulations. Differences in computer game preferences were also noticed by King and Delfabbro [36], who observed that boys were more likely than girls to choose shooter games, RPGs and online strategy games, while girls preferred jigsaw puzzles and simulation games. Funk et al. [37] and Chiu et al. [38] believe that games with violent content are more attractive to men, and that the development of addiction in male gamers is affected by such game attributes as light and sound effects. In a study by Kuntsche [39], almost half of the boys and only $20 \%$ of the girls surveyed cited a violent game as their favourite game.

On the basis of regression, we identified the demographic and family-related factors that were important predictors of online gaming addiction. Male gender, urban residence, psychological and physical parental abuse, mitigation of the mother's child-raising principles by the father in order to present himself to the child as the "better parent", and the child's belief that he/she was responsible for his/her parents altogether explained a quarter of the variance in online gaming addiction. Many researchers who study the determinants of video game addiction draw attention to abnormal relationships in the families of young people who excessively play computer games, disturbed family communication $[20,21,38,40]$ and parental violence [30,41]. Kwon et al. [22] emphasize that family relationships are a more important factor in the development of computer gaming addiction than peer relationships. In their study of a Korean sample, young people were found to increase the amount of time they spent playing online games when they perceived weak ties with their parents, who showed unconscious hostility towards them. Poorer relationships with peers and family were also a feature of excessive video game users in a study by Padilla-Walker et al. [20]. Shen and Williams [21] observed that frequent MMORPG use was associated with abnormal communication in the family and children's sense of loneliness. Litwinowicz [16] found that physically punished girls preferred shooter games, RPGs and MMORPGs to other game genres. Chiu et al. [38] showed that in those families in which parents had better time management skills and placed a greater emphasis on activity planning and entertainment, young people had a less tendency to develop addiction to gaming. Increased social interaction between parents and children also has a protective effect against the development of online gaming addiction, but this does not apply to playing games together [14]. Given the role family relationships play in the development of online gaming addiction, preventive programs aimed at protecting teenagers against this type of addiction should involve parent counseling and psychoeducation.

\section{CONCLUSIONS}

1. Significantly more boys than girls play online games. Boys devote more time to playing and have more severe symptoms of addiction to online games.

2. Adolescent city dwellers spend significantly more time playing online games, mainly to relieve boredom and experience new sensations, than young people living in the countryside.

3. Women living in the city have significantly more severe symptoms of addiction to online games than those living in the countryside.

4. The significant predictors of online gaming addiction include male gender, urban residence, domestic violence, mother's child-raising rules being challenged by the father, and the child's sense of responsibility for his/her parents. 


\section{REFERENCES}

1. Bomba R. Jak badać gry komputerowe? Recenzja książki Fransa Mäyrä pt. „An Introduction to Game Studies. Games in Culture”. Kultura i Historia 2009; $15: 142-5$

2. American Psychiatric Association. Diagnostic and Statistical Manual of Mental D isorders. 5th ed. American Psychiatric Publishing, Arlington, VA; 2013.

3. Müller KW, Janikian M, Dreier M, et al. Regular gaming behavior and internet gaming disorder in European adolescents: results from a crossnational representative survey of prevalence, predictors, and psychopathological correlates. Eur Child Adolesc Psychiatry. 2015;24:565-74.

4. Lopez-Fernandez O, Honrubia-Serrano ML, Baguley T, Griffiths MD Pathological video game playing in Spanish and British adolescents: Towards the exploration of Internet Gaming Disorder symptomatology. Comput Human Behav. 2014;41:304-12.

5. Porter G, Starcevic V, Berle D, Fenech P. Recognizing problem video game use. Aust N Z J Psychiatry. 2010;44(2):120-8.

6. Grüsser SM, Thalemann R, Griffiths MD. Excessive computer game playing: evidence for addiction and aggression? Cyberpsychol Behav. 2007;10(2):290-2.

7. Thomas, NJ Martin FH. Video-arcade game, computer game and Internet activities of Australian students: participation habits and prevalence of addiction. Aust J Psychol. 2010;62(2):59-66.

8. Kuss DJ, Griffiths MD. Internet gaming addiction: A systematic review of empirical research. Int J Ment Health Addict. 2012;10(2):278-96.

9. Jeong E, Kim DW. Social activities, self-efficacy, game attitudes and game addiction. Cyberpsychol Behav Soc Netw. 2011;14(4):213-21.

10. Bathyánny D, Muller KW, Benker F, Wolfing K. Computer game playing: clinical characteristics of dependence and abuse among adolescents. Wiener Klinische Wochenschift. 2009;121(15-16):502-9.

11. Gentile DA. Pathological video game use among youth ages 8 to 18 : a national study. Psychol Sci. 2009;20(5):594-602.

12. Rehbein F, Kleimann M, Mediasci G, Mossle, T. Prevalence and risk factors of video game dependency in adolescence: results of a German nationwide survey. Cyberpsychol Behav Soc Netw. 2010;13(3):269-77.

13. Desai RA, Krishnan-Sarin S, Cavallo D, Potenza MN. Video-gaming among high school students: health correlates, gender differences and problematic gaming. Pediatrics. 2010;126(6):1414-24.

14. Jeong EJ, Kim DW. Social activities, self-efficacy, game attitudes, and game addiction. Cyberpsychol Behav Soc Netw. 2011;14(4):213-21.

15. Young KS. Understanding online gaming addiction and treatment issues for adolescents. Am J Family Ther. 2009;37:355-72.

16. Litwinowicz K. Preferencje gatunków gier komputerowych a osobowość i agresywność u młodzieży gimnazjalnej. Niepublikowana praca magisterska. Łódź, Uniwersytet Łódzki, Wydział Nauk o Wychowaniu. Instytut Psychologii; 2006.

17. King DL, Delfabbro P. Motivational differences in problem video game play. Journal of CyberTherapy and Rehabilitation. 2009;2(2):139-49.

18. Williiams D, Yee N, Caplan S. Who plays, how much, and why? Debunking the stereotypical gamer profile. Journal of Computer-Mediated Communication. 2008;13:993-1018.

19. Mottram AJ, Fleming MJ. Extraversion, impulsivity, and online group membership as predictors of problematic internet use. Cyberpsychol Behav. 2009;12(3):319-21.

20. Padilla-Walker LM, Nelson LJ, Carrol JS, Jensen AC. More than a just game: video game and Internet use during adulthood. J Youth Adolesc. 2010;39(2):103-13.

21. Shen C, Williams D. Unpacking time online: Connecting Internet and massively multiplayer online game use with psychosocial well-being. Communication Research. 2011;38(1):123-49.

22. Kwon J-H, Chung C-S, Lee J. The effects of escape from self and interpersonal relationship on the pathological use of Internet games Community Ment Health J. 2011;47:113-21.

23. Griffiths M, Wood RTA. Risk factors in adolescence: the case of gambling, videogame playing, and the Internet. J Gambl Stud. 2000;16(2-3):199-225.

24. Chan PA, Rabinowitz T. A cross-sectional analysis of video games and attention deficit hyperactivity disorder symptoms in adolescents. Ann Gen Psychiatry. 2006;5(1):6-26.

25. Szpringer M, Horecka-Lewitowicz A, Czerwiak G, Laurman-Jarząbek E. Gry komputerowe a zachowania problemowe młodzieży w wieku 12-13 lat. Studia Medyczne. 2008;12:35-9.

26. Wenzel HG, Bakken IJ, Johansson A, et at. Excessive computer game playing among Norwegian adults: self-reported consequences of playing and association with mental health problems. Psychol Rep. 2009;105(3):123747.
27. Messias E, Castro J, Saini A, et al. Sadness, suicide, and their association with video game and internet overuse among teens: results from the youth risk behavior Survey 2007 and 2009. Suicide Life Threat Behav. 2011;41(3):307-15.

28. Mentzoni RA, Brunborg GS, Molde H, et al. Problematic video game use: estimated prevalence and associations with mental and physical health. Cyberpsychol Behav Soc Netw. 2011;14(10):591-6.

29. Potembska E, Pawłowska B. Właściwości psychometryczne Kwestionariusza do Badania Uzależnienia od Gier Internetowych (KBUGI). Curr Probl Psychiatry. 2014;14(3):135-43.

30. Pawłowska B, Dziurzyńska E. Relacje w rodzinie a uzależnienie od gier komputerowych u młodzieży. Curr Probl Psychiatry. 2012;13(3):196-208

31. Bobrowki K. Czas wolny a zachowania ryzykowne młodzieży. Alkoholizm i Narkomania. 2007;20(3):267-87.

32. Boroń J, Zyss T. Świat gier komputerowych II - badania ankietowe nad ich rozpowszechnieniem wśród młodzieży szkół średnich. Psychiatr Pol. 1996;30(2):267-80.

33. Johansson A, Götestam KG. Problems with computer games without monetary reward: similarity to pathological gambling. Psychol Rep. 2005;95(2):641-50.

34. Poprawa R. W poszukiwaniu psychologicznych mechanizmów problematycznego używania Internetu. In: M. Sokołowski, ed. Oblicza Internetu. Internet w przestrzeni komunikacyjnej XXI wieku. Elbląg: Wydawnictwo PWSZ; 2006. p. 113-24.

35. Pawłowska B, Zygo M, Potembska E, et al. Prevalence of Internet addiction and risk of developing addiction as exemplified by a group of Polish adolescents from urban and rural areas. Ann Agric Environ Med. 2015;22(1):129-36.

36. King DL, Delfabbro P. Understanding and assisting excessive players of video games: a community psychology perspective. Aust Community Psychol. 2009;21(1):62-74.

37. Funk J, Hagan J, Schimming J, et al. Aggression and psychopathology in adolescents with a preference for violent electronic games. Aggressive Behav. 2002;28(2):134-44.

38. Chiu S-I, Lee J-Z, Huang D-H. Video game addiction in children and teenagers in Taiwan. Cyberpsychol Behav. 2004;79(5):571-81.

39. Kuntsche EN. Hostility among adolescents in Switzerland: multivariate relations between excessive media use and forms of violence. J Adolesc Health. 2004;34:230-6.

40. Kwon HK, Kwon JH. The effect of the cognitive-behavioral group therapy for high - risk students of Internet addiction. Kor J Clin Psychol. 2002;21:503-14

41. Pawłowska B, Potembska E, Gleba E, et al. Uzależnienie od Internetu a relacje z rodzicami dziewcząt będących dziećmi alkoholików. Curr Probl Psychiatry. 2011;12(2):179-83.

\section{Corresponding author}

Prof. dr hab. Jolanta Szymańska

Department of Integrated Pediatric Dentistry

Medical University of Lublin

58 Lubartowska St., 20-094 Lublin, Poland

E-mail: szymanska.lublin@gmail.com 